\title{
China's economy: From past to future
}

\author{
VITO TANZI ${ }^{1,2^{*, * *}}$
}

${ }^{1}$ Former Director, Fiscal Affairs Department, International Monetary Fund (IMF), Washington, DC, USA

${ }^{2}$ Honorary President, International Institute of Public Finance, Munich, Germany

\section{ABSTRACT}

Why did China grow so fast in the past four decades? What were the main factors? Important ones were: attitude of government; opening to the world; role of culture; exploitation of technological gap; role of foreign trained students; and role of government in the creation of modern infrastructure. These factors are likely to play a much smaller role in the future while several negative factors -populism, trade wars, environmental obstacles, aging of the population, authoritarianism and others are likely to lead to significantly lower growth rates.

\section{KEYWORDS}

economic growth, factors that contribute to growth, catching up hypothesis, technology gap, human capital, openness, populism, trade wars

\section{JEL CLASSIFICATION INDICES}

F6, 01, 053, P2, P52

\section{INTRODUCTION}

I shall never forget my first two visits to China, both in 1985. The first was a tourist tour, organized for a group of International Monetary Fund (IMF) and World Bank employees, after the Bank-IMF Annual Meetings in the Republic of Korea in September. Going to China at that

\footnotetext{
*E-mail: vitotanzi@msn.com

**Ehtisham Ahmad and Alex Tanzi discussed with me some of the issues in this paper and provided some useful information. I am grateful to both of them.
} 
time was almost as rare and as exciting as going to the moon. One did not know what to find. The second visit, a couple of months later, was as part of a small group of high-level staff of the International Monetary Fund that went to Beijing on an official mission to make early contacts with the Chinese authorities, at a time when China had approached the IMF to become a Fund member and fuller part of the World community. The IMF mission group was hosted in the same Government Guest House which, a short time earlier, had hosted the British Queen, during her official visit to China (see Tanzi (2008) for description of both visits).

The IMF group was well received and held several useful meetings with the Chinese officials, some on various aspects of the working of a market economy, and some on the specifics of the relations between an IMF member country and the IMF. The latter included annual visits to China by IMF staff, provision of data by China to the IMF, complying with Fund rules, and the availability of IMF technical assistance in fiscal, monetary, legal and statistical matters (see IMF, various years). At that time, I was the director of the IMF's Fiscal Affairs Department, a large department staffed by experts in the public finance area, that would play a significant role in China, in the years that followed, with its technical assistance, in taxation and in other fiscal areas (Ahmad et al. 1995).

In one of these meetings, I was asked to elaborate on the economic role that governments play and should play in an economy with a market, as China had started to have in those years. What should a government do in economic matters in such a country? And what would be the limits of the government's interventions? I tried to answer this question, somewhat academically, starting from the views held by Adam Smith, and going forward to the more important roles that governments have played in modern market economies. When I finished my presentation, a Chinese hand went up and the first question I received was: why is there a need for a government role in such an economy? Can't the market do all that needs to be done? It was my first eye-opener in China. I was put in the strange position of defending a government economic role in a country that I thought had a "communist" economy, with a typical "command and control" government.

A second eye-opener came the next day when, in a visit to an outdoor market in old Beijing, in a stand that sold old items, there was a sign, in English, which stated that a free market is more efficient than one controlled by the government. I was surprised that, in what I still thought was "communist" China; a shop could openly display such a sign, without any visible embarrassment or concern. During that visit several Chinese would occasionally approach us in the streets, to exchange the few words that they had learned in English. Clearly, the importance of learning English was already evident in China, in 1985. I learned that some informal groups had come into existence that would meet in city parks to try to converse in Basic English. In that trip we also learned that a pizza restaurant had recently opened in Beijing and was doing well.

A third, and perhaps the most surprising, eye-opener came a few days later, when, in the morning, I received, under my door in the Guest House, a copy of "China Daily", the official, English-language, government newspaper and an article in it caught my attention. The article described the experience of a young lady who had started a private activity by selling fresh flowers. She had been successful in this private activity and she was slowly becoming rich, by local standards. The article commented on her success and also on the fact that it had been attracting the attention of her distant relatives, who had been asking for financial assistance, or for loans, from her.

The unexpected and surprising conclusion of the story, this in an official "communist" newspaper, was that: "in China rich people are very rare, and they need the protection of the 
government”. At that point I concluded that China definitely had a good economic future, and that I would not be surprised if, in future years, its per capita income would be sharply higher, as in fact it was, in the decades that followed. It rose from a very low, single-digit percentage of that of the USA, to a middle-income level in recent years, while creating a large, prosperous and educated middle class, with significantly higher incomes. After almost four decades of extraordinary growth, its economy is now about $20 \%$ of the world economy and its growth is a larger share of the world growth.

I should, perhaps, also mention, in an article to be published in a Hungarian journal, that the year before the visits to China, in 1984, I had been invited by the Hungarian government to provide IMF's technical assistance to Hungary. The request was how to reduce private incentives and private activities, especially those connected with "underground economic activities", that in those years were allowing some individuals to earn high incomes (Tanzi 2010: 71-73). Those private activities were making some Hungarian individuals enjoy higher standards of living than the average population, a development that, at that time, worried the Hungarian authorities.

In 1985, China was still really very poor. One who visits Chinese cities and Chinese shops today cannot possibly imagine just how poor it was then, and how far this country has come in the space of a few decades. It is not an exaggeration to speak of an "economic miracle", a miracle that, in a development without precedence in history, has lifted hundreds of millions of Chinese from abject poverty to a comfortable standard of living. In the years after 1985, China would make an extraordinary transition, from the poor past to a much better economic future. Several important factors would contribute to this "economic miracle". Some are mentioned, in a nontechnical and somewhat impressionistic or narrative way, in the next section.

\section{FACTORS THAT CONTRIBUTED TO CHINA'S GROWTH}

"Economic miracles" happen when a series of factors jointly play a positive role on economies. These factors increase the productivity of the available factors of production, and may increase them, pushing the production frontier of a country beyond where it had been. The government in power, or prevailing religious beliefs or cultural traditions, must not put obstacles to the positive actions of the factors, as they have continued to do in some countries. The government must play a contributing and encouraging role in the process. The assumption of this paper is that the Chinese Government, in the decades since the 1980s, did play an important, contributing role in at least five ways.

A first factor, that often goes unnoticed by economists, is the role that a country's cultural background can play in an economy. China had been a highly cultured country for thousands of years. Furthermore, it had been a country in which knowledge had been respected and considered important and even revered. Cultural proficiency had been given weight and had been admired. The "Mandarins" had become "Mandarins" because of their knowledge. Their positions had been based on merit and not on birth. A strong cultural background, one that values knowledge, can make a country better able and more disposed to absorb different knowledge, when that knowledge becomes available and when governments do not impose obstacles. The willingness and the ability of China to absorb and use new, technical knowledge in recent decades have been extraordinary. Mao's Cultural Revolution had been clearly an 
aberration, or a "dissent into madness", in the Chinese society, as some has described that tragic experience.

In the technical assistance that the IMF provided to China, especially in the decade of the 1990s, it became clear that the modus operandi that the Chinese authorities chose, in the use of the foreign, technical assistance, was unique. It was not the usual one of having foreign experts go to a country, such as China, write a lengthy report, and give it to the authorities, to be adopted, or ignored, depending on the case, as was the routine in most countries. Rather, in China, the modus operandi was different: the Chinese would gather a large group of highly selected, Chinese officials (up to 30), and would have the foreign experts give a serious of lectures, in which they would describe the various, practical ways in which different advanced countries had dealt with a specific issue that interested the Chinese, say the introduction of a value added tax, or the use of a treasury. The Chinese participants in these presentations would listen to the foreign experts, take copious notes, and ask many questions during and after the presentations. Later, they would organize working groups among themselves, to discuss the options and try to reach a consensus, about the option that seemed to be most attractive for China (Tanzi 2008).

Once a preferred option was agreed upon, by the Chinese side, the next step was to choose a town, an office, a ministry, a region, or a public enterprise, to try to adopt the option chosen, to see how well it would work in practice, in a real, Chinese environment. This process had the function of having several Chinese officials learn new techniques, and of reaching some consensus among them, on the preferred option. This experience was definitely different from that of other countries, including Russia, in those years, where the attitude was, often, that the old ways were the best ways, and that the foreign advice was at times seen as an invasion in the domestic, established, and preferred modus operandi. In this latter environment, the reforms made were, at times, more cosmetic than substantive (Tanzi 2010, 2019).

This Chinese attitude and their willingness to get useful knowledge from wherever it was available became evident in the role of education. The Chinese government paid a lot of attention, from 1978 onwards, to the improvement of the educational system in China. Within relatively few years, China was able to create excellent, first and second level, schools, that in recent years have become among the best performing schools in the world, according to the PISA scores, prepared by the OECD. Some schools in Shanghai are now ranked as having the highest achievement scores in the whole world for their students. The quality of universities has also increased significantly and some foreign Nobel Prize Winners have been invited to reach in them.

The good school preparation of students has facilitated their admission to good foreign universities, especially in the USA, the UK, Canada, Australia and Germany, where they could get good university training, especially at the advanced levels (Masters and $\mathrm{PhDs}$ ), in engineering and scientific and business subjects, and return to China, bringing back one of the most important ingredient for economic growth, useful human capital. According to the official Chinese sources, in 2018, 662,000 Chinese students went to study abroad, $44 \%$ went to the USA, and the rest mostly to the UK, Australia, Canada and Germany. 519,000 returned to China. Many of these students came from middle class backgrounds, and most were able to get good jobs in China when they returned. Some of these jobs were in research or teaching institutions. Many of them would contribute to the publication in Chinese of many important foreign books, and would establish several important Chinese, technical reviews. As mentioned, several foreign 
Nobel Prize Winners were invited to teach in China, and important international conferences were organized by the Chinese universities.

Between 1978 and 2018, 5.86 million Chinese studied abroad; 4.32 million completed their studies, and 3.65 million returned to China after completing their studies. The human capital that the millions of students who had studied abroad brought back to China, combined with the hard-working character of the Chinese, inevitably contributed to the rapid reduction in the knowledge and technological gap that had existed in the 1980s, between China and the advanced countries. Two quantitative manifestation of the reduction in that knowledge gap are the number of Chinese "patent applications" per year, and the "range and diversity" of its recent exports.

The number of annual patent applications by China has been rising rapidly and is now very high. It indicates that China no longer needs to borrow (or occasionally to steal) most of the technology that it uses from other advanced countries, as it did in the past. In areas such as mass transportation, communication technologies, solar energy, placing of satellites in space, artificial intelligence, and in some others, China has become a leader. This has made it, undoubtedly, an industrial powerhouse, one capable of competing and often winning internationally. Several of its companies have become leaders in their fields.

In 2018, China applied for 3.3 million patents, for 14.3 million global trademarks, and for 1.3 million industrial designs. Its patent applications were almost half of the world total. As WIPO's 2019 Report stated: "China has been the main driver of global growth of International Patent Filings in recent years". In 2018, there were $11.6 \%$ more patent applications by China, and $1.6 \%$ less by the USA, than in the year before.

With respect to the above data, it has been observed that not all patent applications are accepted, and that the ratio of "patent application" to "patent acceptance" for China, at 24\%, is much lower than that, close to 50\%, for the USA, Germany, the Republic of Korea and Japan. Furthermore, the quality of the Chinese patents is often lower than that for other major industrial countries (Santacreu - Zhu 2018). Still. In spite of these qualifications, the Chinese progress has been remarkable.

Another quantitative indication of the reduction, or even the disappearance of the technological gap for China is an index, generated by a group, at Harvard and MIT, that has included Ricardo Hausman. The index is called the "complexity index". It ranks countries' exports on the basis of the variety of the products that are exported. The basic idea is that the more technologically-advanced is a country, the more diverse will be the range of products that it can export. In this index the leaders are obvious: USA, Germany, Japan, and South Korea. In recent years, China has, sharply, moved up in this index, and is now close to the leaders.

It should be noted that, especially in the early years when the share of Chinese exports in the total world export was small, it was easier for China to find foreign markets and foreign buyers for its products. As the Chinese share of exports in the world's total rose, obstacles started to be imposed by some countries on imports from China, leading to the trade wars in the most current years.

Another factor that in past years played a large role in China, a role facilitated by the type of government that it had, was the extraordinary creation of modern infrastructures, including airports, railroad stations, fast trains, roads, power plants and others. A person that had visited China in the 1980s would immediately appreciate and be amazed by these new, modern marvels. 
When it comes to the building of major infrastructures, there should be little down that a country with a powerful, authoritarian and focused government has a potentially -major advantage, over democratic countries, because the government has to pay little attention to the property rights of many small owners, who, in democratic countries can challenge, delay, or even stop the creation of large infrastructures, by refusing to collaborate, or to the views of small, organized groups, that often oppose major infrastructure projects on various grounds. The protection of property rights and the political power of some private groups often give some individuals and organized groups the power to oppose some infrastructural developments in various countries. Recent experiences of countries such as the UK, Italy and others support this conclusion. The USA has been unable to create a fast train service that would serve the crowded Eastern corridor of the USA, between Boston and Miami.

In China property rights over land have remained in the hands of the (national and regional) government and the views of small private groups of citizens could be ignored. This gave the government a relatively free hand that allowed it to build some of the world most modern infrastructures within a few decades. That infrastructure made it possible and facilitated the high growth rate that could use a large reservoir of rural workers who had been engaged in unproductive agricultural activities. The Chinese government could also ignore negative externalities that were being created, such as major environmental problems that in the long run would create difficulties.

A final positive factor that should be mentioned in connection with China's fast growth over past decades was the phenomenal saving rate that it has had over the past decades. That high rate gave the country the possibility to have exceptionally high rates of investment without foreign borrowing and even to invest some of that saving in foreign assets, including in the US government bonds, or in infrastructures in the developing countries. The "Silk Road Initiative" is a recent example.

The high saving rate must have been significantly promoted by the high growth rate of the economy and of personal incomes, and by the fact that current personal consumption is often influenced more by the average of past incomes than by the current income and by the expected future incomes. Additionally, the Chinese government in past years did not run large fiscal deficits, but public enterprises borrowed heavily accumulating large liabilities.

In conclusion, a country that starts from far behind and that has the right conditions for channeling resources to more productive uses, as was the case with China, has an advantage over more advanced countries, that do not have a gap that facilitates the process of catching up and have to generate new technological knowledge. This is the well-established theory of convergence (Barro 2016). In the past decades China had benefited from being in such a situation. It is not likely that the future decades will present it with similar, fortunate opportunities (Zhang 2016; Zhu et al. 2019).

\section{LIKELY OBSTACLES TO FUTURE GROWTH}

In the previous Section we listed five factors that likely contributed to the exceptionally high growth rates that characterized and transformed the Chinese economy in recent decades. Recently the growth rates have slowed down somewhat, though, at about $6 \%$ per year, they are still very high by the standards of the advanced countries. It seems reasonable to expect that, in 
the future years, China's economic growth will fall and become closer to the normal international levels. A similar pattern was followed in the past by some other countries, which, after experiencing a very high economic growth for some decades, growth rates that were considered "economic miracles", saw the rates fall significantly. Among these countries could be mentioned Japan and the Republic of Korea, in Asia, and Germany, Italy and Ireland, in Europe. This pattern is consistent with what has been defined the "convergence theory" suggested by several economists.

As there were several factors, identified in the previous section that contributed to the high growth of China in the past decades, there are factors that are likely to play some roles in the reduction of future growth. Some of these are mentioned below, again without making any attempt at quantifying them, or even at conveying a sense of their relative importance.

Perhaps, the first factor to mention is the move by China, in the past decades, towards what might be considered the production frontier. As China converged from being a very poor and technologically backward country toward becoming an emerging economy, the technological space that had separated it from the advanced countries was progressively reduced. As a consequence, it became more difficult for China to simply copy, from other countries, easily available technologies, that it could use. It was increasingly forced to develop its own technologies, and its ways of producing goods and services that its own population wanted and that the rest of the world wanted to buy.

The above factor would also have to consider the fact that it is far easier for a small economy to increase its exports, when those exports become more competitive and they are still a small share of the world's total exports, than it is for a large country, especially one of China's size to do so. Chinese exports have become an increasingly important share of the world's total in recent years. They have come to compete with similar products exported by other large countries, and by the established foreign competitors. This, for example, would be the case with the export of cars, which are now produced in large quantities in China. In the future, local demand would have to play a leading role, than it did in the past, in providing a demand for these products.

Sill connected with the above factor is the fact that the world seems to have become more populist and less open in recent years, and populism is having a growing impact on free trade, that had been based on globally shared rules. Populism is stimulating trade restrictions and "trade wars", as the one now under way between China and the US. In a populist world, it may be more difficult for a globally integrated large economy to maintain a high rate of growth, by relying on exports, as China had done in the past decades.

Another factor that is likely to play a role is growing respect for the environment. In the past decades China's economic development, notoriously, had paid little attention to the impact that it was having on the environment, both that of China itself and that of the world at large. There is ample evidence that China became one of the most polluted countries in the world, and that the past growth was often bought at very high environmental costs. Some estimates, made by the World Bank and by other sources in the past years, had shown that, when corrected for environmental costs, China's growth rates would have been much lower. In the future, respect for the environment will make high growth more difficult.

Environmental costs are also affecting the health and the life expectancy of many Chinese citizens. They have been generating many early deaths in China, where, occasionally, air and water pollution have reached dangerous levels. China's environmental costs, especially those 
associated with the burning of coal, to generate electricity, are also having a major impact on global warming, that will also affect China's and other countries' policies toward China. China has been a leader in the production of solar panels to get electricity directly from the sun. However, so far, its consumption of coal has remained very high. China has continued to rely on coal and to build power plants that rely on coal.

China remains a major polluter and a much polluted, though richer, country. A clean environment is a superior good, the demand for it is likely to increase with the growth of per capita income. Furthermore, hundreds of millions of Chinese are still waiting to get cars and air conditioners. To deal with these demands, and to ensure a cleaner environment will require policies that will inevitably have some significant and negative impact on its measured economic growth. Also, there may be a growing unwillingness on the part of the rest of the world to buy Chinese goods produced under conditions that contribute to global warming. There have already been proposals by some major economists, including Joseph Stiglitz, to tax these products when they are imported.

Another factor that will affect China's future growth is demographics. For many years, China had pursued a so-called "one child policy", which allowed couples to have only one child. This policy was promoted by the government to reduce the growth of the Chinese population. While this policy that was recently relaxed, may have succeeded in reducing the population growth, it also led to an aging population problem. The increase in life expectancy was taking place at the same time when the one child family rule was in effect. The consequence was that the "dependency ratio", the ratio of retirees to those still working, has been increasing rapidly. That ratio will soon reach the levels that inevitably will have a direct impact on economic growth.

The increase in the dependency ratio will also force the government to increase taxes on the fewer workers and on those with high incomes, to finance public spending, for both health care and pensions, and for facilities for the aged. The growth in the dependency ratio is likely to become a major negative factor for economic growth in future years. This factor exists also in several advanced countries. However, current estimates indicate that it will be particularly important in China.

The economic role that the government may have played, and that may play in China's future, might also be an important factor, even though it is a factor a bit more difficult to assess. The kind of government that China had in the past decades probably had a positive effect on its growth. Some likely change in that role in the future may reduce its positive impact. An argument made by some economists, including Kolodko $(2018,2020)$, is that the Chinese-style, authoritarian government, led by a "Communist Party", facilitated the introduction of policies that facilitated growth, a view that was endorsed in the previous section of this paper. In brief, the authoritarian government had facilitated the creation of a first-rate infrastructure network. Such a network would have been difficult to create in a more democratic environment, one that guaranteed strong individual property rights, and that made possible for some groups of citizens, or even for individual citizens, to oppose and delay some large infrastructures.

The questions to ask are, first, whether what may have been good for China in the past, may still be good in the future. Second, whether the future Chinese government might become more exposed to the pressures of specific citizens or groups of citizens who want to promote their personal or group interests in a society that is becoming less egalitarian. Inevitably, in the less egalitarian countries, those who have high incomes have more connections and end up having more political power. 
While in the past a strong government may have been helpful in promoting changes that were clearly assumed to lead to fast economic development, it is less likely that in the future needed changes would be as obvious, and that a government will be equally capable of making or forcing them. Future investment decisions would have to be guided much more by market forces, and governments are less good at responding to those forces. The continued existence of state enterprises would inevitably create strong pressures on the government to make policy decisions that help them but that may conflict with market forces. Rent seeking and corruption by members of the Communist Party, or by their relatives, would play a larger role, in an economy where being rich has become "glorious" and which now contains many very rich individuals, including some of the world billionaires. The Chinese government has been attempting to fight corruption. However, as happened in Russia, with time the true believers would be slowly replaced by opportunists, in a society where equality of income is no longer a firm social goal (Tanzi 2008, 2019). The rise of living standards for many would no longer compensate for the creation of large and growing differences in relative incomes. The Gini coefficient for China has been rising significantly over the years and it no longer describes an egalitarian society.

Better educated and more affluent citizens are likely to increase pressures on the government to give more space to democratic forces, to influence policy decisions, as indicated by the recent events in Hong Kong. A country in which millions of students go to study abroad, in countries with democratic institutions, and where they are exposed to democratic thinking, where the Internet and other sources expose the population to liberal ideas and institutions, where a large share of the population has a high enough income that allows them to travel to other countries, and where many Chinese now make to the published lists of the richest individuals in the world, is not likely to continue to accept passively to be run by a "communist party" that will make decisions for all. Some individuals; may also join that communist party for opportunistic reasons. Changes are likely to take place and those changes will make it more difficult for China to keep growing at the astronomical rates of the past.

\section{CONCLUDING COMMENTS}

This short paper has speculated on some factors that are likely to have contributed to the phenomenal growth of the Chinese economy over the past four decades, and that created a "Chinese economic miracle". In recent years the rate of growth has slowed down, from more than $10 \%$ per year to about $6 \%$. This paper has argued that the growth rate is likely to keep falling, as happened in other countries that also experienced "economic miracles". How quickly and how fast this reduction will take place, is difficult to even speculate at this time. China clearly has some potential to keep growing for a while longer, barring some unexpected events, such as a financial crisis. Hundreds of millions of Chinese are still operating in rural areas and in low productivity occupations. Bringing them closer to the production frontier will still offer possibilities for high growth for China, but there will be increasing breaks imposed on that growth.

While this paper was being completed, the coronavirus pandemic made its unwelcome appearance. The impact of that pandemic on the world and on China in particular is likely to be serious but cannot be addressed in this article. Whether it will be just a short-run blip in the growth pattern of China and of other countries, or it will have longer term consequences only time will tell. 


\section{REFERENCES}

Ahmad, E. - Qiang, G. - Tanzi, V. (1995): Reforming China's Public Finances. Washington, DC: IMF.

Barro, R. J. (2016): Economic Growth and Convergence, Applied to China. China and World Economy, 24(5): 5-19.

Kolodko, G. (2018): Socialism, Capitalism or Chinism. Communist and Post-Communist Studies, 51(4): 285-298.

Kolodko, G. (2020): China and the Future of Globalization: The Political Economy of China's Rise. London, New York, Oxford, New Delhi, Sidney: I.B. Tauris.

Santacreu, A. M. - Zhu, H. (2018): What Does China's Rise in Patents Means? A Look at Quality and Quantity. Economic Research, No. 14, St. Louis, Federal Research Bank.

Tanzi, V. (2008): Peoples, Places and Policies: China, Japan and Southeast Asia. New York: Jorge Pinto Books.

Tanzi, V. (2010): Russian Bears and Somali Sharks: Transition and Other Passages. New York: Jorge Pinto Books.

Tanzi, V. (2019): Observing Russia's Transition. МИР ПЕРЕМЕН, The World of Transformations, The International Scientific and Public Journal, No. 2, (in Russian).

World Intellectual Property Organization (WIPO) (2019): World Intellectual Property Indicators. Geneva. Zhang, L. (2016): Rebalancing in China - Progress and Prospects. IMF Working Paper, No. 16/183.

Zhu, M. - Zhang, L. - Peng, D. (2019): China's Productivity Convergence and Growth Potential - A Stocktaking and Sectoral Approach. IMF Working Paper, No. 19/263. 